\title{
The Pro12Ala polymorphism in the PPAR- $y 2$ gene is not associated to obesity and type 2 diabetes mellitus in a Cameroonian population
}

\author{
Edith Pascale M. Mato ${ }^{1,2+}$, Priscille Eunice Pokam-Fosso ${ }^{1,2+}$, Barbara Atogho-Tiedeu ${ }^{1,2}$, Jean Jacques N. Noubiap ${ }^{3,4}$, \\ Marie-Solange Evehe ${ }^{1,2}$, Rosine Djokam-Dadjeu ${ }^{1,2}$, Olivier Sontsa Donfack ${ }^{1,2}$, Elvis Ndonwi Ngwa ${ }^{1,2}$, \\ Magellan Guewo-Fokeng ${ }^{1,2}$, Wilfred F. Mbacham ${ }^{1,5}$, Eugene Sobngwi ${ }^{2,6,7^{*}}$ and Jean Claude Mbanya ${ }^{2,6,7}$
}

\begin{abstract}
Background: Peroxisome proliferator-activated receptor gamma 2 (PPAR- $y 2$ ) is a transcription factor with a key role in adipocyte differentiation, lipid storage and glucose homeostasis. The Ala allele of the common Pro12Ala polymorphism in the isoform PPAR- $\gamma 2$ is at the center of many controversies because in some populations, it has been observed to be associated with T2DM or obesity but, not in others. The aim of this study was to investigate the association of Pro12Ala polymorphism in the PPAR- $\gamma 2$ gene with susceptibility to obesity or T2DM in a Cameroonian population.

Methods: This case-control study included 62 obese, 60 T2DM patients and 120 controls (60 non obese and 60 patients without T2DM), all unrelated and of Cameroonian origin. PPAR- 22 was examined by genotyping for Pro12Ala using the Restriction Fragment Length Polymorphism - Polymerase Chain Reaction (PCR - RFLP).
\end{abstract}

Results: A portion of the 270 base pair bands of the PPAR- $\gamma 2$ gene was successfully amplified. The Ala 12 variant was totally absent from the study population, all participants being homozygote Pro/Pro.

Conclusion: PPAR- $\gamma 2$ Pro12Ala gene polymorphism may not be associated with obesity and T2DM. These results suggest that, PPAR-Y2 is unlikely a major gene for obesity or T2DM in the study population.

Keywords: Obesity, Type 2 diabetes mellitus, Genetic association, PPAR- 2 , PPAR gamma2, Pro12Ala

\section{Background}

Type 2 diabetes mellitus and obesity are a major global health problem. The prevalence of obesity and T2DM is increasing dramatically and WHO reports that more than 500 million people are obese [1] and 387 million have diabetes [2]. T2DM is a metabolic disease characterized by hyperglycemia that can occur as a result of impaired insulin secretion, insulin resistance in peripheral tissues and increased hepatic glucose output [3],

\footnotetext{
* Correspondence: sobngwieugene@yahoo.fr

${ }^{\dagger}$ Equal contributors

${ }^{2}$ Laboratory for Molecular Medicine and Metabolism, Biotechnology Center University of Yaoundé I, Yaoundé, Cameroon

${ }^{6}$ Department of Internal Medicine and Specialties, Faculty of Medicine and Biomedical Sciences, University of Yaoundé I, Yaoundé, Cameroon Full list of author information is available at the end of the article
}

while obesity occurs as the result of chronic energy imbalance involving physical inactivity, excessive energy intake, depression, sleep disorders and low socioeconomic status [4]. Obesity and T2DM are called "multifactorial" or "complex" diseases because, they depend on multiple genetic factors as well as environment.

Some genes are thought to be involved in the development of T2DM and obesity amongst which, the peroxisome proliferator activated receptor gamma $(P P A R-\gamma)$ gene. PPAR- $\gamma$ is a member of a subfamily of the nuclear receptor superfamily of a ligand activated transcription factors (PPAR) that consists of 3 subtypes: PPAR- $\alpha$, PPAR- $\beta$ and PPAR- $\gamma$. PPAR $\gamma 2$ which results from mRNA alternative splicing of PPAR- $\gamma$ is 
expressed predominantly in the adipose tissue. It has been shown that PPAR- $\gamma$ has an important role in adipocyte differentiation and that it regulates lipid metabolism and sensitivity to insulin [5]. A CCA-GCA mutation leading to the substitution of proline by alanine on codon 12 of exon B of the PPAR- $\gamma 2$ has been described. This mutation was first identified by Schuldiner's group in 1997 with different ethnic population showing various allelic frequencies that is probably modulated by environmental and other genetics factors. Caucasians have the highest frequency (12\%), followed by Mexican Americans (10\%), West Samoans (8 \%), African Americans (3\%), while Chinese have the lowest (1\%) [6]. In Africans and Asians, frequency of Ala 12 is low (1-3 \%). The Ala isoform may lead to a less efficient stimulation of the PPAR- $\gamma$ target genes and predisposes to lower levels of adipose tissue mass accumulation which in turn may be responsible for improved insulin sensitivity [7]. The large and increasing burden of non communicable diseases and the potential for modifying risk through adequate treatments and lifestyle alterations make the identification of methods for early detection of persons at greater risk an important public health challenge. Knowledge of genetic polymorphisms that allow accurate quantification of T2DM and obesity risk will allow the development of complex models with diagnostic and prognostic. Many studies clearly show heterogeneous effects of this polymorphism on predicting susceptibility to the risk of T2DM and obesity in various populations [810]. This preliminary study aimed to investigate the association of Pro12Ala with T2DM and obesity in a Cameroonian population.

\section{Methods}

\section{Study population}

This is a case-control study involving 62 obese adults and 60 non-obese controls, and 60 T2DM patients and 60 non-diabetic healthy controls of Cameroonian origin, aged 20 years old and above. Obese and T2DM patients were recruited from the outpatient clinic of the National Obesity Center of the Yaoundé Central Hospital, and non-obese controls from the general population. For all participants, data was collected on the sex and age; we measured height, waist and hip circumference to the nearest $0.5 \mathrm{~cm}$, and weight in light clothes to the nearest $0.1 \mathrm{~kg}$, and we then calculated the body mass index (BMI) as weight in $\mathrm{kg} / \mathrm{height}^{2}$ in $\mathrm{m}^{2}$, and the waistto-hip ratio. Obesity was defined as a BMI $\geq 30 \mathrm{~kg} /$ $\mathrm{m}^{2}$. We measured the resting blood pressures using standardized procedures with an automatic sphygmomanometer Omron HEM-705 CP (Omron Corporation, Tokyo, Japan).

\section{Biochemical assays}

Fasting plasma glucose (glucose oxidase-peroxidase method), serum cholesterol (cholesterol oxidase phenol4amino antipyrene peroxidase method), serum triglycerides (glycerol phosphatase oxidase - phenol4-amino antipyrene peroxidase method), and high-density lipoprotein (HDL)cholesterol (cholesterol oxidase phenol4-amino antipyrene peroxidase method) were measured on a spectrophotometer (UV Mini 1240) using Chronolab kits (Chronolab Systems, Barcelona, Spain). Low-density lipoprotein (LDL)-cholesterol was calculated using the Friedwald's formula [11].

\section{DNA extraction and molecular genotyping}

Genomic DNA was isolated from dried blood spots on Whatmann filter paper by the chelex method [12]. The Pro12Ala polymorphism of the PPAR 2 gene was analysed using the Polymerase Chain Reaction-Restriction Fragment Length Polymorphism (PCR-RFLP) method. Exon B was amplified with a T3 Thermocycler (BIOMETRA) using the forward primer: 5'-GCCAATTCAAGCCCAGTC-3' and the reverse primer: 5'-GATATGTTTGCAGACAGT GTATC-3' (SIGMA-ALDRICH). Each PCR was performed in a final volume of $15 \mu \mathrm{l}$ containing $100 \mathrm{ng}$ of DNA extract, $5 \mathrm{pmol}$ of each primer, $100 \mu \mathrm{mol} / \mathrm{L}$ of each deoxynucleotide triphosphate (dNTP), $0.5 \mathrm{U}$ of Hot Star Taq DNA polymerase (QIAGEN), $1.5 \mu \mathrm{l}$ of PCR buffer with $1 \mathrm{mmol} /$ $\mathrm{L}$ of $\mathrm{MgCl}_{2}$ and $7.8 \mu \mathrm{l}$ of nuclease free water. The reaction was carried out under the following conditions: predenaturation at $95{ }^{\circ} \mathrm{C}$ for $15 \mathrm{~min}$, followed by 30 cycles of denaturation at $95{ }^{\circ} \mathrm{C}$ for $1 \mathrm{~min}$, annealing at $56{ }^{\circ} \mathrm{C}$ for $1 \mathrm{~min}$ and elongation at $72{ }^{\circ} \mathrm{C}$ for $1 \mathrm{~min}$, and a final extension at $72{ }^{\circ} \mathrm{C}$ for $10 \mathrm{~min}$. Electrophoresis was conducted to confirm the 270 bp PCR products. Six microliters of positive PCR products were then digested at $37^{\circ} \mathrm{C}$ overnight with $0.2 \mu \mathrm{l}$ of the Bst UI restriction endonuclease using the New England Buffer 4 recommended by the manufacturer (NEW ENGLAND BIOLABS, UK). Digestion products were analysed by electrophoresis using a $3 \%$ agarose gel. In order to verify whether our samples contained an enzyme inhibitor, we carried out a mix-in experiment using the Tsp 5091 restriction endonuclease to digest the mixture containing Pro12Ala amplicons and rs 12255372 amplicons with a restriction site for the Tsp 5091 enzyme.

\section{Statistical analysis}

Statistical analysis was performed using IBM SPSS for Windows, version 20.0 (IBM Corp., Armonk New York, USA). Quantitative variables were expressed as mean (Standard deviation (SD). The clinical and laboratory characteristics of cases and controls were compared using chi-square tests. The continuous variables have been studied by ANOVA T test, Mann Whitney $\mathrm{U}$ test. A $p$ value $<0.05$ was considered statistically significant. 


\section{Results}

The biochemical and anthropometric results for the study population are shown in Tables 1 and 2 . In the group of obese status (Table 1), fasting blood glucose was significantly higher in obese subjects $(p=0.027)$, as well as systolic blood pressure $(p<0.001)$ and diastolic blood pressure $(p<0.001)$. Considering lipid profile, only total cholesterol levels were significantly higher in obese subjects compared to non-obese ones $(p=0.04)$. While, in the group of T2DM status (Table 2), the diastolic blood pressure $(p=0.034)$, total Cholesterol $(p<0.001)$, LDL - Cholesterol $(p<0.001)$ and the atherogenic index $(p<0.001)$ were significantly higher in non T2DM patients compared to the T2DM patients. The genotype analysis revealed that a portion of the $270 \mathrm{pb}$ band of the PPAR- $\gamma 2$ gene.Ala12 variant was totally absent from the study population, all participants being homozygote Pro/Pro.

\section{Discussion}

Africa is experiencing a surge on obesity prevalence and related morbidity and mortality within the context of one of the most rapid epidemiological transition in the world history [1,2]. Obesity and T2DM are caused by combined effect of many factors that could be environmental, psychosocial and genetic. Although the epidemic is attributable to the trend of decreased physical activity and increase caloric intake, these external factors are playing out on a genetic background to determine body mass and susceptibility to obesity-related disease [4]. From the point of view of Evolutionary Genetics, it has been hypothesized that there are some "thrifty genes" that have been fixed in our genome for thousands of years to prevent hunger, cold and calamities which hinder feeding [13]. On the contrary, PPAR $\gamma 2$ is an "unthrifty"

Table 1 Characteristics of obese patients and controls

\begin{tabular}{llll}
\hline Parameters & Cases $(n=62)$ & Controls $(n=60)$ & $p$ value \\
\hline Age $($ years $)$ & $43(11)$ & $34(12)$ & $<0.001$ \\
BMI $\left(\mathrm{Kg} / \mathrm{m}^{2}\right)$ & $34.22(4.62)$ & $22.10(1.70)$ & $<0.001$ \\
WHR & $0.86(0.07)$ & $0.81(0.06)$ & $<0.001$ \\
FPG $(\mathrm{mg} / \mathrm{dL})$ & $96.81(11.74)$ & $92.03(11.08)$ & 0.027 \\
SBP $(\mathrm{mmHg})$ & $131.13(20.05)$ & $116.98(16.45)$ & $<0.001$ \\
DBP $(\mathrm{mmHg})$ & $80.53(10.90)$ & $70.77(10.97)$ & $<0.001$ \\
T-C $(\mathrm{mg} / \mathrm{L})$ & $190.5(35.89)$ & $180.68(26.85)$ & 0.040 \\
TG $(\mathrm{mg} / \mathrm{dL})$ & $135.79(19.47)$ & $131.81(18.26)$ & 0.247 \\
HDL-C $(\mathrm{mg} / \mathrm{dL})$ & $49.02(7.89)$ & $47.89(5.37)$ & 0.360 \\
LDL-C $(\mathrm{mg} / \mathrm{dL})$ & $114.84(33.29)$ & $106.46(25.02)$ & 0.119 \\
Al & $3.93(0.68)$ & $3.80(0.62)$ & 0.293 \\
\hline
\end{tabular}

Data are expressed as mean (standard deviation)

FPG Fasting Plasma Glucose, SBP Systolic Blood Pressure, DBP Diastolic Blood

Pressure, $H D L-C$ high density lipoprotein cholesterol, $L D L-C$ low density

lipoprotein cholesterol, TG triglycerides, Al Atherogenic

index $=$ total cholesterol/HDL-cholesterol
Table 2 Characteristics of the study population (T2DM status)

\begin{tabular}{llll}
\hline Parameters & $(n=60)$ & Controls $(n=60)$ & $p$ value \\
\hline Age (years) & $60(20)$ & $50(12)$ & $<0.001$ \\
BMI $\left(\mathrm{Kg} / \mathrm{m}^{2}\right)$ & $29.08(5.74)$ & $29(4.76)$ & 0.602 \\
WHR & $0.95(0.08)$ & $0.87(0.07)$ & $<0.001$ \\
FPG $(\mathrm{g} / \mathrm{L})$ & $1.78(0.77)$ & $0.92(0.09)$ & $<0.001$ \\
SBP $(\mathrm{mmHg})$ & $137(24)$ & $138(25)$ & 0.775 \\
DBP $(\mathrm{mmHg})$ & $79(12)$ & $85(14)$ & 0.034 \\
T-C $(\mathrm{g} / \mathrm{L})$ & $1.65(0.23)$ & $1.97(0.39)$ & $<0.001$ \\
TG $(\mathrm{g} / \mathrm{L})$ & $1.42(0.29)$ & $1.49(0.27)$ & 0.171 \\
$\mathrm{HDL}-\mathrm{C}(\mathrm{g} / \mathrm{L})$ & $0.49(0.10)$ & $0.51(0.6)$ & 0.274 \\
$\mathrm{LDL}-\mathrm{C}(\mathrm{g} / \mathrm{L})$ & $0.88(0.21)$ & $1.16(0.36)$ & $<0.001$ \\
$\mathrm{Al}$ & $2.31(0.68)$ & $1.86(0.56)$ & $<0.001$ \\
\hline
\end{tabular}

Data are expressed as mean (standard deviation)

FPG Fasting Plasma Glucose, SBP Systolic Blood Pressure, DBP Diastolic Blood

Pressure, HDL-C high density lipoprotein cholesterol, LDL-C low density lipoprotein cholesterol, TG triglycerides, Al Atherogenic

index $=$ total cholesterol $/ \mathrm{HDL}$-cholesterol

gene which has been shown to play an important role in adipocyte differentiation, regulation of lipid metabolism and sensitivity to insulin $[7,14,15]$. It has a protective effect against type 2 diabetes mellitus, and is associated to obesity [14-16]. Data on the genetic epidemiology of $P P A R \gamma 2$ are very scare in populations of African ancestry. This study aimed to investigate the frequency of the proline to alanine substitution in the human PPAR $\gamma^{2}$ gene and its association with obesity and T2DM in a Cameroonian population. We found that the Ala allele was completely absent in our study population, and the Pro allele was fixed. The frequencies of the Ala vary widely across ethnic populations. A typical black africans population (Berba, African Bantu) shows no Ala12 allele [17], whereas Ethiopian African population (Amhara) [17], African American population (African ancestry on Southwest USA) [18] and Oriental populations (Japanese, Singapore Chinese, Han Chinese and Koreans) exhibit a small Ala12 frequency [19-22]. Typical Far East Asian populations and North African Caucasoids (Tunisians) and Middle East Caucasoids (Qataris) show also a Ala12 low frequency [23, 24]. North Indian Sikhs have a high Ala12 mutation frequency [25], as well as Europeans and Amerindians [13, 26, 27]. Our findings are therefore consistent with data from the literature which show that; overall, black africans tend to show low or null Ala12 allele frequencies, while most other populations have a significant frequency, particularly European Caucasoids. These genetic epidemiologic patterns may be explained by the fact that the Pro12 allele seems to be the wild allele which must have occurred before modern humans left Africa [14], while the Ala 12 allele must have occurred in Caucasoids later on [14]. The variability in Ala 12 frequencies in Caucasians and Caucasoids may have 
been due to evolutionary fitness forces pertaining to feeding and metabolic adaptation.

\section{Conclusion}

This study suggests that PPAR- $\gamma 2$ Pro12Ala mutation is not associated with the development of obesity and T2DM in the Cameroonian population. Our findings are consistent with existing data which show no Ala12 allele in typical black africans populations.

\section{Ethics statement}

The study was granted approval by the National Ethical Review Board of the Cameroon Ministry of Public Health. Written informed consent was obtained from all the participants. The study was conducted in accordance with the Helsinki Declaration.

\section{Availability of data and materials}

Data will be made available by the corresponding author upon request.

\section{Abbreviations}

ANOVA: analysis of variance; DNA: deoxyribonucleic acid; PCR: polymerase chain reaction; PPAR- $\gamma 2$ : peroxisome proliferator-activated receptor gamma 2; T2DM: type 2 diabetes mellitus; WHO: World Health Organization.

\section{Competing interests}

The authors declare that they have no competing interests.

\section{Authors' contributions}

Study conception and design: ES, BAT, RDD, MSE, WFM, JCM, PPF, EPMM. Data collection: EPMM, PPF, BAT, ES, OSD, MFG, ENN, RDD, MSE. Statistical analysis: PPF, JJNN, OSD. Drafting: EPMM, PPF, JJNN, ES, BAT. Critical discussion and manuscript revision: JJNN, ES, BAT, RDD, MSE, MFG, WFM, JCM, PPF, EPMM, ENN. All the authors approved the final version of the manuscript.

\section{Acknowledgements}

We gratefully acknowledge all the patients who have accepted to take part in this study. We are also grateful to the staff of the National Obesity Centre and the Biotechnology Center of the University of Yaoundé I for their contribution in the recruitment of patients and the handling of samples, assays and records. This work was supported by a grant from the Vlaamse inter universitaire Raad (VLIR-UOS ZEIN2007PR343). The study was also supported by the North East Diabetes Trust, Newcastle upon Tyne, and the Institute of health and Society, Newcastle University, UK.

\section{Author details \\ 'Department of Biochemistry, Faculty of Science, University of Yaoundé I, Yaoundé, Cameroon. ' 2 Laboratory for Molecular Medicine and Metabolism, Biotechnology Center, University of Yaoundé I, Yaoundé, Cameroon. ${ }^{3}$ Department of Medicine, Groote Schuur Hospital and University of Cape Town, Cape Town, South Africa. ${ }^{4}$ Medical Diagnostic Center, Yaoundé, Cameroon. ${ }^{5}$ Laboratory for Public Health Research and Biotechnologies, Biotechnology Center, University of Yaoundé I, Yaoundé, Cameroon. ${ }^{6}$ Department of Internal Medicine and Specialties, Faculty of Medicine and Biomedical Sciences, University of Yaoundé I, Yaoundé, Cameroon. ${ }^{7}$ National Obesity Center, Yaoundé Central Hospital and Faculty of Medicine and Biomedical Sciences, University of Yaoundé 1, Yaoundé, Cameroon.}

Received: 27 July 2015 Accepted: 28 April 2016

Published online: 12 May 2016

\section{References}

1. Kelly T, Yang W, Chen CS, Reynolds K, He J. Global burden of obesity in 2005 and projections to 2030. Int J Obes (Lond). 2008;32:1431-7.
2. International Diabetes Federation. IDF Diabetes Atlas. 6th ed. Brussels; 2013. Available at: http://www.idf.org/diabetesatlas. Accessed: February 20, 2015.

3. Guillausseau PJ, Meas T, Virally M, Laloi-Michelin M, Médeau V, Kevorkian JP. Abnormalities in insulin secretion in type 2 diabetes mellitus. Diabetes Metab. 2008;34 Suppl 2:S43-8.

4. Park Y, Zhu S, Palaniappan L, Heshka S, Carnethon MR, Heymsfield SB. The metabolic syndrome: prevalence and associated risk factor findings in the US population from the Third National Health and Nutrition Examination Survey, 1988-1994. Arch Intern Med. 2003;163:427-36.

5. Tavares V, Hirata RD, Rodrigues AC, Monte O, Salles JE, Scalissi N, Speranza RC, Hirata MH. Association between Pro12Ala polymorphism of the PPAR-g2 gene and insulin sensitivity in Brazilian patients with type-2 diabetes mellitus. Diabetes Obes Metab. 2005;7:605-11.

6. Stumvoll M, Hans $\mathrm{H}$. The peroxisome proliferator activated receptory2 Pro12Ala polymorphism. Diabetes. 2002:51:2341-7.

7. Deeb SS, Fajas L, Nemoto M, Pihlajamaki J, Mykkanen L, Kuusisto J, Laakso M, Fujimoto W, Auwerx J. A Pro12Ala substitution in PPARy2 associated with decreased receptor activity, lower body mass index and improved insulin sensitivity. Nat Genet. 1998:20(3):284-7.

8. Hara K, Okada T, Tobe K, Yasuda K, Mori Y, Kadowaki H, Hagura R, Akanuma Y, Kimura S, Ito C, Kadowaki T. The Pro12Ala polymorphism in PPAR gamma2 may confer resistance to type 2 diabetes. Biochem Biophys Res Commun. 2000;217:212-6.

9. Muller YL, Bogardus C, Beamer BA, Shuldiner AR, Baier LJ. A functional variant in the peroxisome proliferator-activated receptor gamma2 promoter is associated with predictors of obesity and type 2 diabetes in Pima Indians. Diabetes. 2003;52:1864-71.

10. Meirhaeghe A, Amouyel P. Impact of genetic variation of PPARY in humans. Mol Genet Metab. 2004;83:93-102.

11. Friedewald WT, Levy RI, Frederickson DS. Estimation of the concentration of low density lipoprotein cholesterol in plasma, without use of preparative ultracentrifuge. Clin Chem. 1972;18:499-502.

12. Ereqat $\mathrm{S}$, Nasereddin A, Azmi K, Abdeen Z, Amin R. Impact of the Pro12Ala polymorphism of the PPAR-Gamma 2 gene on metabolic and clinical characteristics in the Palestinian type 2 diabetic patients. PPAR Res. 2009. doi:10.1155/2009/874126.

13. Neel JV. The "thrifty genotype" in 1998. Nutr Rev. 1999;57:S2-9.

14. Arnaiz-Villena A, Fernandez-Honrado M, Areces C, Enriquez-deSalamanca M, Abd-El-Fatah-Khalil S, Coca C, Arribas I, Algora M, Rey D. Amerindians show no association of PPAR-y2gene Ala12 allele and obesity: an "unthrifty" variant population genetics. Mol Biol Rep. 2013; 40(2):1767-74.

15. Ruiz-Narvaez E. Is the Ala12 variant of the PPARG gene an "unthrifty allele"? J Med Genet. 2005:42:547-50.

16. Gouda HN, Sagoo GS, Harding AH, Yates J, Sandhu MS, Higgins JP. The association between the peroxisome proliferator-activated receptorgamma2 (PPARG2) Pro12Ala gene variant and type 2 diabetes mellitus: a HuGE review and meta-analysis. Am J Epidemiol. 2010;171:645-55.

17. Scacchi R, Pinto A, Rickards O, Pacella A, De Stefano GF, Cannella C, Corbo RM. An analysis of peroxisome proliferatoractivated receptor gamma (PPAR-gamma 2) Pro12Ala polymorphism distribution and prevalence of type 2 diabetes mellitus (T2DM) in world populations in relation to dietary habits. Nutr Metab Cardiovasc Dis. 2007;17:632-41.

18. The International HapMap 3 Consortium. Integrating common and rare genetic variation in diverse human populations. Nature. 2010; 467(7311): 52-58.

19. Mori $H$, Ikegami $H$, Kawaguchi $Y$, Seino S, Yokoi N, Takeda J, Inoue I, Seino $Y$, Yasuda K, Hanafusa T, et al. The Pro12 $\rightarrow$ Ala substitution inPPAR-gamma is associated with resistance to development of diabetes in the general population: possible involvement in impairment of insulin secretion in individuals with type 2 diabetes. Diabetes. 2001;50:891-4.

20. Tai ES, Corella D, Deurenberg-Yap M, Adiconis X, Chew SK, Tan CE, Ordovas JM. Differential effects of the C1431T and Pro12Ala PPARgamma gene variants on plasma lipids and diabetes risk in an Asian population. J Lipid Res. 2004;45:674-85.

21. Liu XL, Zhang FL, Zhou ZY, Zhao HL, Shen GM, Baohan WY, Duan ZY, Li W, Zhang JW. Analysis of two sequence variants in peroxisome proliferator activated receptor gamma gene in Tajik population at high altitudes and Han population at low altitudes in China. Mol Biol Rep. 2010;37:179-84.

22. Oh EY, Min KM, Chung JH, Min YK, Lee MS, Kim KW, Lee MK. Significance of Pro12Ala mutation in peroxisome proliferator-activated receptor-gamma2 in Korean diabetic and obese subjects. J Clin Endocrinol Metab. 2000;85:1801-4. 
23. Ben Ali S, Ben Yahia F, Sediri Y, Kallel A, Ftouhi B, Feki M, Elasmi M, Haj-Taieb S, Souheil O, Sanhagi H, Slimne H, Jemaa R, Kaabachi N. Gender-specific effect of Pro12Ala polymorphism in peroxisome proliferator-activated receptor gamma-2 gene on obesity risk and leptin levels in a Tunisian population. Clin Biochem. 2009;42:1642-7.

24. Badii R, Bener A, Zirie M, Al Rikabi A, Simsek M, Al Hamaq AO, Ghoussaini M, Froquel P, Wareham NJ. Lack of association between the Pro12Ala polymorphism of the PPAR-gamma 2gene and type 2 diabetes mellitus in the Qatari consanguineous population. Acta Diabetol. 2008;45(1):15-21.

25. Sanghera DK, Ortega L, Han S, Singh J, Ralhan SK, Wander GS, Mehra NK, Mulvihill JJ, Ferrel RE, Nath SK, Kamboh MI. Impact of nine common type 2 diabetes risk polymorphisms in Asian Indian Sikhs: PPARG2 (Pro12Ala) IGF2BP2, TCF7L2 and FTO variants confer a significant risk. BMC Med Genet. 2008;9:59.

26. Costa V, Casamassimi A, Esposito K, Villani A, Capone M, lannella R, Shisano B, Ciotola M, Di Palo C, Corrado FC, Santangelo F, Giugliano D, Ciccodicola A. Characterization of a novel polymorphism in PPARG regulatory region associated with type 2 diabetes and diabetic retinopathy in Italy. J Biomed Biotechnol. 2009;2009:126917.

27. Gonzalez Sanchez JL, Serrano RM, Fernandez PC, Laakso M, Martinez Larrad MT. Effect of the Pro12Ala polymorphism of the peroxisome proliferatoractivated receptor gamma-2 gene on adiposity, insulin sensitivity and lipid profile in the Spanish population. Eur J Endocrinol. 2002;147(4):495-501.

\section{Submit your next manuscript to BioMed Central and we will help you at every step:}

- We accept pre-submission inquiries

- Our selector tool helps you to find the most relevant journal

- We provide round the clock customer support

- Convenient online submission

- Thorough peer review

- Inclusion in PubMed and all major indexing services

- Maximum visibility for your research

Submit your manuscript at www.biomedcentral.com/submit

) Biomed Central 